\title{
Balancing Historical Roots and Future Growth: China’s Foreign Policy
}

\author{
Lisa Guo ${ }^{1}$, Pit L. Chiu ${ }^{2}, \&$ Hiroshi Ito ${ }^{3}$ \\ ${ }^{1}$ Faculty of Business, University of Alberta, Edmonton, Canada \\ ${ }^{2}$ Department of Management, City University of Hong Kong, Hong Kong, China \\ ${ }^{3}$ Faculty of Economics, Nagoya University, Aichi, Japan \\ Correspondence: Hiroshi Ito, School of Economics, Nagoya University of Commerce and Business, Nisshin, \\ Aichi, Japan. Tel: 81-561-73-2111. E-mail: hito@nucba.ac.jp
}

\author{
Received: February 24, $2017 \quad$ Accepted: March 7, $2017 \quad$ Online Published: April 19, 2017 \\ doi:10.5539/ass.v13n5p1 URL: https://doi.org/10.5539/ass.v13n5p1
}

\begin{abstract}
Whereas many know about China's economic growth in recent years, the most people have little understanding regarding how the country's historical roots and political structure have contributed to development. Through an analysis of relevant literature, this article examines China's historical roots and political structure as they affect its foreign policy decisions that have contributed to shaping the country's national development. It is suggested that a deeper understanding of this relationship will help Western nations interpret China's current and future policy decisions in order to forecast the potential significance of its global influence over the next decade.
\end{abstract}

Keywords: China, foreign policy, development path, economic growth

\section{Introduction}

With the world's largest population and the second largest economy, the People's Republic of China's industrial activity over the last few decades has made a strong impression on the global community. "Made in China" has become a common household phrase recognized worldwide. In the span of only three decades from 1979 to 2014 , China's annual real GDP growth averaged approximately 10\%, and it has become the world's largest manufacturer, exporter, and holder of foreign currency reserves (Morrison, 2015). This growth, which has drawn the attention of many, particularly Western nations, also compares favorably against the average annual growth in real GDP of their regional rivals, Japan (7.7\%) and South Korea (9.1\%) from 1950 to 1980 (OECD, 2009). Given its current rate of growth, many believe that China has the potential to become the world superpower in the near future.

While many in North America and Western Europe know about China's tremendous growth, they have little understanding regarding how the country's historical roots and political structure have contributed to its development. As detailed later, China's state capitalism, which is a historical and political byproduct, is a prime example of what Westerners have little clear understanding. Since, according to widely held economic theory, private property and competition play a crucial role in sustainable growth and economic development (Acemoglue \& Robinson, 2012), "[f]rom a Western perspective, state capitalism epitomizes one of the main impediments to sustained growth in China" (Schweinberger, 2014, p. 169).

The country's growth can be largely attributed to the 1978 economic reforms implemented by Deng Xiaoping, which led to more liberalized foreign trade that opened China up to the world and marked the beginning of the economic model termed as "socialist market economy with Chinese characteristics" (Li, Liu \& Wang, 2015, p. 2). This model consists of regular socialism with added features of capitalism in order to maximize social good. However, many economists today argue that China's system is a stronger example of state capitalism which involves a combination of guidance from open market forces along with the state rule in order to maximize profit (Li et al., 2015).

The differences between China's state-capitalist economy compared to the market-oriented economies of North America and Europe make it difficult for North Americans and Europeans to obtain a clear understanding of China's economic behavior. In reality, China is a nation with a long and complex economic and political history that has shaped its foreign policy decisions. Having experienced extensive changes in political and economic systems from one century to the next, China's complex and long history strongly influences the behaviour and 
perspective of the nation's leaders today. The degree to which the Communist Party of China (CPC), the current ruling political party, influences China's foreign policy decisions is not a concept easily understood by democratic countries. In order to better understand and predict the direction of its future growth, Western nations must look further into China's history.

Through an analysis of relevant literature, this paper seeks to evaluate the extent to which China's historical roots and political structure affects its foreign policy decisions. It is proposed that an understanding of this relationship will help Western nations interpret China's current and future foreign policy decisions in order to forecast the potential significance of its global influence over the next decade.

\section{Method}

This paper is based on a review of existing literature. We mainly selected literature about the country's history, foreign policy, political reforms, and economic development based on state capitalism during and especially after the Cultural Revolution because China started growing economically fast since the era. It is important to understand China's history and political structure to understand the remarkable growth it has experienced in recent decades.

\section{Literature review}

\subsection{State Capitalization in a Global Context}

According to Lyons (2007), "[s]tate Capitalism is the use of government controlled funds to acquire strategic stakes around the world" (p. 119). Deng's intentions to integrate China into the global market, by freeing market and working toward "capitalism" while its political regime remains communist, involved a more cautious and low profile approach to foreign relations, where China tried to "avoid international conflicts, or to freeze or appease them when they [arose]" (Blaauw, 2013, p. 13). China's prompt rise from being a struggling country to becoming the world's second largest economy has garnered much international attention and as a result, many have argued that this low profile approach to foreign relations is no longer a fitting strategy. With more expectations placed upon China to step forward as a "global power" and not just a "global actor" (Blaauw, 2013, p. 1), there has been a further need for China's foreign policy to evolve and pave the way for it to advance into a leadership role in the international market.

Also, China's position in the global economy is one in which its state capitalist system continuously comes into contact with Western capitalist economies such as that of the USA. On a purely technical level, state capitalism and Western capitalism share many structural similarities, and the differences lie primarily in the ideological backing of those structures. Both systems operate on the basis of privately held businesses competing in the marketplace. In a Western capitalist economy, these businesses are controlled by private individuals or are publicly traded on the stock market by private individuals and other businesses. In a state capitalist economy, this marketplace still exists and private individuals participate in the market: however the government is overwhelmingly the major player in that marketplace. The government controls the flow of investment and is able to direct national development and advance certain priorities based on how financial resources are allocated. Additionally, businesses in a Western capitalist economy operate largely for the purpose of making a profit for the owners and stakeholders while businesses in a state capitalist economy operate to make a profit that can then be reallocated by the government to advance its strategic goals. It may also be important to note that there exist different state capitalism systems exist. For instance, Russia's state capitalism is different from that of China's in that the latter has "a direct interest in commercial development which is lacking in Russia" because "China extracts rents from commerce, while Russia does it from resources (Schweinberger, 2014, p. 172).

\subsection{Origins of state capitalism in China}

State capitalism in China originated from a desire to increase national economic growth during a time when China was transitioning out of a centrally planned economic system, which was originally implemented to support the heavy-industry focused development strategy at the time (Lin, Cai, \& Li, 2003). During the country's pre-economic reform period before 1978, Lin et al. (2003) attributes the inefficient, high-cost nature of China's poor economic condition during the period to be a result of this heavy-industry focused development strategy. By 1978, these circumstances caused Deng Xiaoping, the leader of the Communist Party of China, to adopt a new economic strategy involving market-oriented reforms in hopes that it would stimulate economic growth and raise living standards (Morrison, 2015). In order to address China's socio-economic slump and low standards of living since the war against Japan and the Chinese Civil War from 1937 to 1949, including the 1966-1976 Cultural Revolution era, Deng's policies in 1979 emphasized the need to adapt China's economic system to the socio-economic realities of China by shifting towards more capitalist techniques of 'modern' economies. As 
Herrala and Jia (2015) describe, "China has witnessed decades of strong development of the private corporate sector and a reduction in the role of state-owned enterprises (SOEs)" (p. 163).

In 1979, China started deregulating its market by opening more sectors that permitted the foreign direct investment (FDI) to participate in. Also, the low-tax strategy on foreign investors was a great incentive for foreign investment. It then became the largest developing country recipient of FDI in the mid-1990s (Das, 2003). Also, as shown in Table 1, China greatly transitioned labor from agriculture into the manufacturing sector (Siraj 2011).

Table 1. Sectoral composition of GDP of China (\% of GDP)

\begin{tabular}{ccccc}
\hline & 1980 & 1990 & 1997 & 2005 \\
\hline Agriculture & 36.1 & 26.8 & 17.1 & 11.4 \\
Manufacturing & 25.4 & 25.3 & 31.1 & 34.1 \\
Services & 30.3 & 39.3 & 38.0 & 40.2 \\
Other industries & 8.2 & 8.2 & 13.8 & 14.3 \\
\hline
\end{tabular}

China's new economic policies involved a shift away from state-intervention in the market, de-collectivization of agriculture (freeing agriculture from collective political control), an increase in private home ownership, permitting entrepreneurs to start businesses, and opening up the country to foreign trade and investment (Ross, Zheng, \& Prime, 2015). China recorded an average growth rate of industrial value-added? (GDP growth-by-industry) of $9.5 \%$ in the $1980 \mathrm{~s}$ and $13.5 \%$ in the 1990 s (Lo \& Li, 2011). As China further progressed as a country, it became recognized as an equal partner in the world economic community after joining the World Trade Organization (WTO) in 2001.

\subsection{Features of State Capitalism in China}

Chinese state capitalism is defined as "a political, social, and economic system which combined state power with some policy tools and institutions of liberal capitalism to promote a sustained and rapid growth of the Chinese GDP and economic development" (Schweinberger, 2014, p. 172). Since China's transition into a market system on the economic level, the Communist Party of China has been able to maintain its socialist authority on the political level (Baobo, Kobayashi, \& Sano, 1999). Without clearly defining what a socialist market economy entails, this sudden shift has resulted in Party-controlled foreign policy decisions and the government acting as a direct player in the market. In the case of state capitalism in China, the importance of governmental influence alongside a growing private sector can be clearly seen through the functioning of SOEs (Li et al., 2015). These are companies that function in a similar manner to Western companies but they are owned and controlled by the state. Particularly during Hu Jintao's administration (2003-13), China's economic policy increasingly favored state-owned firms (Herrala \& Jia, 2015). Instead of profits being equally distributed among the population, they are retained by the SOEs and used to maximize profit. These companies have always been an important mechanism for the CPC to maintain control within the economy and have been seen as an "extension of the Party's power into the marketplace" (Qiu, 2015, p. 7).

In response to rampant corruption, Xi Jinping's recent "new round of SOE reform and his anti-corruption campaign" (Qiu, 2015, p. 6) is targeted towards fighting the macroeconomic imbalance within the country and increasing efficiency by striking down corruption and introducing more privatization to SOEs. However, given that SOEs are one of the most valuable methods for the Party to extend its authority, there will likely not be any extreme measures taken by the Party to privatize immediately. As long as national prosperity is upheld within the coming years and the Party is able to relatively contain the amount of corruption amongst SOEs, these state-owned vehicles will remain a prominent part of China's strategic economic interests.

\section{Discussion}

In the context of Chinese state capitalism, the state can be seen to be a principal actor that uses the market for political gain. These SOEs provide a degree of market competition; however, they ultimately allow the state to strategically control the direction of the economy.

The Party's dominant role in providing support to targeted economic sectors and aggressively driving economic growth by supporting SOEs and government policies is seen to be a significant factor behind China's continuous development. That is, the result of state capitalism is the ability of the Communist Party of China to motivate investment and business activities based on their own strategic economic interests, largely through the utilization of SOEs. Essentially, state capitalism combines the market orientation of capitalism while retaining the emphasis 
that communism places on government direction of the economy.

Despite the overall similarities between the Western capitalist and state capitalist systems, two key issues continue to impact business relationships between China and the West. First, the communist roots of the Chinese economy, in combination with the inclusion of the word 'communist' in the name of the Communist Party of China, continue to cause underlying Cold War ideological tensions to resurface. Although today's Communist Party of China is communist in name only, the historical strength of Cold War ideological differences, and the relatively recent end of the Cold War overshadows the fact that China's economy is technically capitalist (Coase \& Wang, 2013). Second, when foreign companies consider doing business with China, issues are often raised in the areas of human and workers' rights violations. These issues are more related to the fact that China has an authoritarian government that is choosing not to prioritize regulation in these areas, than they are related to China's economic system.

If anything, these issues could actually be described as being symptomatic of China being a capitalist economy business is operating with profit, not human rights, as a priority. While human and workers' rights violations are certainly a legitimate issue to be considered when contemplating the creation of a business relationship, in terms of technical compatibility, state capitalism and western capitalism are sufficiently similar to function collaboratively.

Due to the mixed responses of neighboring countries, China has recognized the need to adjust its approach to handling interactions with neighboring nations. Since the 18th Party Congress in November 2012 and the start of $\mathrm{Xi}$ Jinping's rule, a new political era for China has already begun to shape itself in the form of visible changes in their approach to international affairs. Some perceive these changes as a shift towards a less aggressive direction, in part due to the need to address increasing domestic issues at home (Hanemann \& Rosen, 2012). Having suddenly stepped into the global spotlight, it does not appear that China will be able to properly undertake the responsibilities of a global superpower without resolving their internal concerns first. Some key reform measures unveiled at the Third Plenum of the 18th Congress address internal policy issues including: deepening economic reform to allow the market to play a more "decisive" role in allocating resources while still holding onto a dominant state ownership, expanding construction of free-trade zones in inland and border areas combined with relaxing investment restrictions, and persisting in protecting maritime interests while remaining dedicated to handling US relations in a more open-minded manner (Yizhou, 2014). It can be noted that there are many contradictory elements to this policy; one of the main contradictions being China's attempt to integrate into the global system by strengthening relationships and moving towards a freer market while still abiding strictly by the principles of its deeply-rooted socialist structure. Xi Jinping has emphasized China's intention to continue to authoritatively rule the domestic landscape with the control of the Communist party. This has struck up a debate on whether China intends to actively follow through with these new initiatives or whether they are merely part of a larger plan prepared by the Party.

Another point recognized in the Plenum is that China's interaction and cooperation with the U.S. within the next decade will significantly define the world's future. There is a complex interdependence that currently exists between the two nations, and China's foreign policy is reflective of its understanding that if it intends to take on a superpower role, it must not clash with the U.S. The Asia Rebalance Policy, initiated by the U.S., posed a clear threat to China which contributed to the view that the U.S. is a potential obstacle in China's ultimate rise to power as a nation (Yizhou, 2014). So far, China has been careful in how it handles its affairs and relations with the U.S., although there is apparent discomfort at the dominance and power of the U.S.. China's actions that can be observed thus far imply that China will take a more open-minded approach to its relations with the U.S.: however China will ultimately view the American superpower as a challenge that must be faced in a timely and calculated manner.

\section{Conclusion}

China's history offers some insight as to why the government takes such a prominent role in the economy, and why their economic system has changed, rather dramatically, since the middle of the 20th century. Although China has a distinctly different historical context than the nations that make up North America and Europe, the government's policy change towards a system of state capitalism has greatly improved China's compatibility with the global economy. Since state capitalism generally shares the same market orientation as capitalism does in the west, foreign firms can comfortably interact with Chinese firms, as it is understood that they approach each other with reasonably similar goals and understandings. However, if China is to fully take advantage of the potential growth opportunities that capitalism is able to offer, the government will have to overcome a number of substantial issues. 
First, they will have to overcome issues of negative perception, stemming from human rights abuses, lax safety standards and the like, and second, they will have to overcome a number of internal issues, such as income disparity and official corruption. Overall, China's future is uncertain. State capitalism in China is still in the process of being defined, and as such, the policy of the Chinese government is continually changing, which can lead to inconsistent and sometimes confusing responses. Until China is able to adopt a firmer economic policy that enables other nations to soundly gauge what the country's intentions are, it will struggle to maintain long-term growth regardless of how well its economy performs in the short term and will encounter continued resistance to their integration into the global economy.

\section{Acknowledgments}

We thank Ezra Anton Greene for editing this paper.

\section{References}

Acemoglu, D., \& Robinson, J. A. (2012). Why nations fail? New York: Crown Publishers.

Baobo, J., Kobayashi S., \&Sano, J. (1999). The "Three Reforms" in China: Progress and Outlook. Retrieved from http://www.jri.co.jp/english/periodical/rim/1999/RIMe199904threereforms/

Blaauw, E. et al. (2013). The driving forces behind China's policy- has China become more assertive? Retrieved from https://economics.rabobank.com/publications/2013/october/the-driving-forces-behind-chinas-foreignpolicy-has-china-become-more-assertive/\#bb93e3d0-1282-4ced-afd6-682d272731 ed

Chow, G. (2003). The Impact of Joining WTO on China's Economic, Legal and Political Institutions. https://doi.org/10.1111/j.1468-0106.2003.00213.x

Coase, R., \& Wang, N. (2013). How China Became Capitalist. Retrieved from http://www.cato.org/policy-report/januaryfebruary-2013/how-china-became-capitalist

Das, D. K. (2013). China and the Asian economies: Mutual acceptance, economic interaction and interactive dynamics. Journal of Contemporary China, 22, 1089-1105. https://doi.org/10.1080/10670564.2013.795317

Hanemann, T., \& Rosen, B. (2012). The Rise in Chinese Overseas Investment and What It Means for American Businesses. China Business Review: The Magazine of the U.S.- China Business Council. Retrieved from: $\mathrm{http} / / / \mathrm{www} . c h i n a b u s i n e s s r e v i e w . c o m / t h e-r i s e-i n-c h i n e s e-o v e r s e a s-i n v e s t m e n t-a n d-w h a t-i t-m e a n s-f o r-a m e r i$ can-businesses/

Herrala, R., \& Jia, Y. (2015). Toward state capitalism in China. Asian Economic Papers, 14(2), 163-175. https://doi.org/10.1162/ASEP_a_00360

Li, X., Liu, X., \& Wang, Y. (2014). A Model of China's State Capitalism. Hong Kong University of Science \& Technology (HKUST). https://doi.org/10.2139/ssrn.2607429

Lin, J. Y., Cai, F., \& Li, Z. (2003). The China Miracle: Development Strategy. The Chinese University Press.

Lo, D., \& Li, G. (2011). China's economic growth 1978-2007: Structural-instructional changes and efficiency attributes. J. of Post-Keynesian Economics, 34(1), 59-84. https://doi.org/10.2753/PKE0160-3477340103

Lyons, G. (2015). State capitalism: The rise of sovereign wealth funds. Journal of Management Research, 14(2), 119-120.

Morrison, W. (2015). China's Economic Rise: History, Trends, Challenges, and Implications for the United States. Retrieved from https://www.fas.org/sgp/crs/row/RL33534.pdf

OECD. (2009). OECD Reviews of Regulatory Reform OECD Reviews of Regulatory Reform: China Defining the Boundary between the Market and the State: Defining the Boundary between the Market and the State. Retrieved from https://books.google.ca/books?id=rA_WAgAAQBAJ\&pg=PA30\&lpg=PA30\&dq=GDP+\#v $=$ onepage $\& \mathrm{q}=\mathrm{GDP} \& \mathrm{f}=$ false

Qiu, Z. (2015). The Impact of SOE Reform on Chinese Overseas Investment. China Brief: a Journal of Analysis and Information, 15(2), 6-10. Retrieved from https://jamestown.org/program/the-impact-of-soe-reform-onchinese-overseas-investment/\#.VSb_lZPF_3q

Ross, J., Zheng, J., \& Prime, K. S. (2015). What can be learned from China's success? Journal of Chinese Economic and Business Studies, 14(1), 51-68. https://doi.org/10.1080/14765284.2015.1132932

Schweinberger, A. (2014). State capitalism, entrepreneurship, and networks: China's rise to a superpower. Journal of Economic Issues, 8(1), 169-180. https://doi.org/10.2753/JEI0021-3624480108 
Siraj, M. (2011). China and India: A comparative analysis of their integration into the global economy. http://www.paecon.net/PAEReview/issue 57/Siraj57.pdf

Slee, C. (2009). China today: Socialist or Capitalist? Links International Journal of Socialist Renewal. Retrieved from http://links.org.au/node/1355

Swaine, M. (2015). China: The Influence of History. Retrieved from http://carnegieendowment.org/2015/01/14/china-influence-of-history

Yizhou, W. (2014). China's New Foreign Policy: Transformations and Challenges Reflected in Changing Discourse. The Asan Forum: An Online Journal. Retrieved from http://www.theasanforum.org/chinas-newforeign-policy-transformations-and-challenges-reflected-in-changing-discourse/

\section{Copyrights}

Copyright for this article is retained by the author(s), with first publication rights granted to the journal.

This is an open-access article distributed under the terms and conditions of the Creative Commons Attribution license (http://creativecommons.org/licenses/by/4.0/). 